\title{
Host immune response in chronic hepatitis $C$ infection: involvement of cytokines and inflammasomes
}

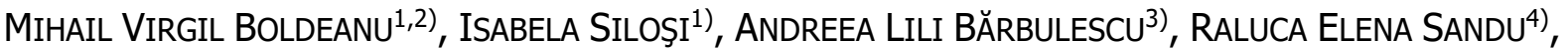

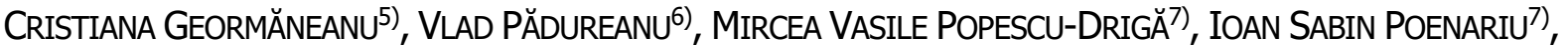 \\ CRISTIAN AdRIAN Siloşi ${ }^{8)}$, ANCA MARILENA UNGUREANU ${ }^{9)}$, ANDA LORENA DIJMĂRESCU ${ }^{10)}$, LIDIA BOLDEANU $\left.{ }^{9}\right)$
}

\author{
1) Department of Immunology, University of Medicine and Pharmacy of Craiova, Romania \\ 2) Medico Science SRL - Stem Cell Bank Unit, Craiova, Romania \\ 3) Department of Pharmacology, University of Medicine and Pharmacy of Craiova, Romania \\ 4) Department of Biochemistry, University of Medicine and Pharmacy of Craiova, Romania \\ 5) Department of Emergency Medicine and First Aid, University of Medicine and Pharmacy \\ of Craiova, Romania \\ ${ }^{6)}$ Department of Internal Medicine, University of Medicine and Pharmacy of Craiova, Romania \\ 7) PhD Student, University of Medicine and Pharmacy of Craiova, Romania \\ 8) Department of Surgery, University of Medicine and Pharmacy of Craiova, Romania \\ 9) Department of Microbiology, University of Medicine and Pharmacy of Craiova, Romania \\ ${ }^{10)}$ Department of Obstetrics and Gynecology, University of Medicine and Pharmacy of Craiova, \\ Romania
}

\begin{abstract}
Chronic liver disease is a major health issue worldwide and chronic hepatitis $\mathrm{C}(\mathrm{CHC})$ is associated with an increased risk of cirrhosis and hepatocellular carcinoma (HCC). There is evidence that the hepatitis $\mathrm{C}$ virus (HCV) infection is correlated with immune senescence by way of immune activation and chronic inflammation, which lead to increased metabolic and cardiovascular risk, as well as progressive liver damage. Both the innate and adaptive immunity are firmly tied to the prognosis of an infection with HCV and its response to antiviral therapy. $\mathrm{HCV}$ is therefore associated with increased pro-inflammatory status, heightened production of cytokines, prolonged systemic inflammation, as well as increased morbidity and mortality, mainly due to the progression of hepatic fibrosis and HCC, but also secondary to cardiovascular diseases. Viral hepatic pathology is increasingly considered a disease that is no longer merely limited to the liver, but one with multiple metabolic consequences. Numerous in vitro studies, using experimental models of acute or chronic inflammation of the liver, has brought new information on immunopathological mechanisms resulting from viral infections and have highlighted the importance of involving complex structures, inflammasomes complex, in these mechanisms, in addition to the involvement of numerous proinflammatory cytokines. Beyond obtaining a sustained viral response and halting the aforementioned hepatic fibrosis, the current therapeutic "treat-to-target" strategies are presently focused on immune-mediated and metabolic disorders, to improve the quality of life and long-term prognosis of CHC patients.
\end{abstract}

Keywords: chronic hepatitis C, cytokines, inflammasomes, inflammasome nucleotide-binding domain, leucine-rich repeat protein 3.

\section{a Introduction}

Chronic liver disease is a significant global health issue and the most prevalent etiologies are represented by non-alcoholic fatty liver disease (NAFLD), alcoholic liver disease, chronic hepatitis B (CHB) and chronic hepatitis $\mathrm{C}$ (CHC) [1]. CHC, caused by the hepatitis $\mathrm{C}$ virus $(\mathrm{HCV})$, affects over 71 million people globally and is correlated with an increased risk of cirrhosis, as well as hepatocellular carcinoma (HCC), ultimately causing 399000 deaths annually [2].

In Romania, the overall prevalence of viral hepatic $\mathrm{C}$ pathology was estimated to be $4.9 \%$, but recent studies have reported a percentage of 3.2 [3]. It can be assumed that more than one million people have anti-HCV antibodies, and if roughly $70 \%$ have active disease, this will be regarded as a public health problem [4].

Furthermore, the presence of the $1 \mathrm{~b}$ genotype is notable (the prevalence in Romania is $92.6 \%$; this prevalence is also recorded in the countries of Central and Eastern Europe, some countries in North Africa, Central and South America) [4], for it implies a lower response to antiviral therapy, making the need for both a higher dose and an extended therapeutic regimen, a particularly costly endeavor [5].

There is evidence that an HCV infection is associated with immune senescence, immune activation and chronic inflammation, which bring about an increased metabolic and cardiovascular risk, as well as progressive liver damage. Both innate and adaptive immunity is significantly tied to the prognosis of an $\mathrm{HCV}$ infection, as well as its response to antiviral therapy [6].

Research conducted in recent decades has focused on the study of the involvement of multiprotein complexes (inflammasomes) in the mechanisms involved in innate immunity. Inflammasomes are considered as caspaseactivating complexes, but roles in intracellular signaling have also been reported, through mediation or even

This is an open-access article distributed under the terms of a Creative Commons Attribution-NonCommercial-ShareAlike 4.0 International Public License, which permits unrestricted use, adaptation, distribution and reproduction in any medium, non-commercially, provided the new creations are licensed under identical terms as the original work and the original work is properly cited. 
involvement in the transmission of intracellular signaling. They also appear to have the ability to be involved in the recognition of pathogens, including liver viruses, in the mechanisms involved in oxidative stress and in insulin resistance respectively [7].

Since 2002, Martinon et al. showed that after the formation of these complexes between cysteine-dependent aspartate-directed protease-1 (caspase-1) and inflammasomes, pro-inflammatory mediators are released, such as interleukin-1beta (IL-1 $\beta$ ) and IL-18. In the formation of these complexes, participate in most cases nucleotidebinding oligomerization domain (NOD)-like receptor (NLR) molecules [8]. It was also observed that in addition to caspase-1, other elements can also participate in the formation of these complexes: cysteine-dependent aspartatedirected protease-5 (caspase-5), a pyrin and C-terminal caspase-recruitment domain (PYCARD), also known as apoptosis-associated speck-like protein containing a CARD (ASC) $[9,10]$.

Studies have highlighted that there is a close relationship between a chronic HCV infection and the promotion of inflammation and liver disease, as well as between IL-1 $\beta$ release and formation followed by activation of the inflammasome nucleotide-binding domain and leucinerich repeat protein 3 (NLRP3) [11].

\section{무 $\mathrm{CHC}$ infection and immune response}

The liver, through the diversity of liver cells, is the key site involved in inflammatory processes. Also, important cells, such as myeloid cells [dendritic cells (DCs), neutrophils and macrophages (cells in which the virus does not have the ability to reproduce quickly)] are responsible for the synthesis of many effectors involved in triggering, mediating and regulating immune responses, both from innate and adaptive immunity: cytokines, adipokines, chemokines, reactive oxygen species (ROS) [12].

The innate immunity defense is the first to react via pattern recognition receptors (PRRs), which have the ability to recognize microbial pathogen-associated molecular patterns (PAMPs) and danger-associated molecular patterns (DAMPs). The receptors from the PRRs category are represented by: Toll-like receptors (TLRs), NLRs, retinoicacid inducible gene I (RIG)-I-like receptors (RLRs) and lastly C-type lectin receptors (CLRs) [8].

Among the cells of innate immunity, natural killer cells (NK) and natural killer T (NKT) cells are the first cells that trigger the immune response [13]. Their activation is done through type I interferons (IFNs), a category that includes interferon-alpha (IFN- $\alpha$ ), interferon-beta (IFN- $\beta$ ) and interferon-omega (IFN- $\omega$ ), but also by type III IFNs [subtype with three members, IL-29 or interferon-lambda 1 (IFN- $\lambda 1)$, IL-28A or interferon-lambda 2 (IFN- $\lambda 2$ ) and IL-28B or interferon-lambda 3 (IFN- $\lambda 3$ )] [14]. Activated NK and NKT cells will secrete type II IFNs, interferongamma (IFN- $\gamma$ ), also known as immune IFN, which together with tumor necrosis factor-alpha (TNF- $\alpha$ ) are important effectors actively involved in innate immune response [15-18].

During an infection, activated macrophages and DCs produce a range of cytokines (IL- $1 \beta$, TNF- $\alpha$, IL-6), chemokines [C-X-C motif chemokine ligand 8 (CXCL8) or IL-8) and certain adhesion molecules $(\alpha \mathrm{X} \beta 2, \alpha \mathrm{D} \beta 2)$ and cluster of differentiation $11 \mathrm{c} /$ cluster of differentiation 18 (CD11c/CD18)] [19]. Also, DCs have the property of presenting viral antigens to naïve $\mathrm{T}$ - and $\mathrm{B}$-cells, via molecules of the major histocompatibility complexes (MHC) class I and class II [20]. Following said interaction, complexes form between the viral epitopes and the MHC, on the one hand, and T-cell receptors (TCR) on the other, bringing about the activation of T-cells within the systemic cellular immune response. Activated T-cells proliferate as well as differentiate into effector or memory T-cells [21].

It is worth pointing out that cytotoxic T-lymphocytes (CTLs), CD8+ T-cell subpopulations, become activated and subsequently begin exerting their cytolytic function, killing virus-infected cells (through apoptosis-mediated cytolysis) and secreting cytokines, such as IFN- $\beta$, IL-12, IL-1, and IL-18. Besides, cytotoxic CD8+ T-cells can produce IFN- $\gamma$ and TNF- $\alpha$ [22]. IFN- $\beta$ is important for directly inhibiting viral replication and increasing $\mathrm{MHC}$ class I up-regulation [23].

After activation, other CD4+ T-cell subsets become engaged in mediating the adaptive immune response by producing T-helper type 1 (Th1) cytokines, pro-inflammatory cytokines, such as IL- 2 , IFN- $\gamma$ and TNF- $\alpha$, implicated in the cell-mediated immune response [24]. The CD4+ Tcells also secrete T-helper type 2 (Th2) cytokines and anti-inflammatory cytokines (IL-4, IL-10, IL-13), which modulate the humoral immune response [25]. It has previously been established that T-cells can self-regulate their activity by way of synthesizing IL-10 and tumor growth factor-beta (TGF- $\beta$ ), which inhibit T-cell proliferation and cytokine synthesis either directly or via other cytokines [26, 27].

An important role in inducing/modulating the activity of cells involved in immune responses is also attributed to the $\mathrm{HCV}$ core proteins. Following the encoding and posttranslational process, the HCV genome consists of three structural proteins [core protein (nucleocapsid protein) C; the envelope glycoproteins, E1 along with E2], as well as seven non-structural proteins [p7, NS2, NS3 (helicase/ protease), NS4A, NS4B, NS5A and NS5B [ribonucleic acid (RNA) polymerase] [28]. Thus, studies have shown that the HCV core protein can selectively suppress IL-12 synthesis by DCs, or inhibit T-cells proliferation by direct or indirect action $[29,30]$. It has also been observed that HCV NS3 and NS4 proteins stimulate the formation of IL-10 producing monocytes, with the cytokine having an immunosuppressive effect on the production of IFN $-\gamma$ by CD4+ T-cells [31].

Soluble mediators found in patients with an $\mathrm{HCV}$ infection attract pro-inflammatory cells, metabolically activating them and increasing vascular permeability. Depending on their time of release, they are classified as the line I mediators [complement system, histamine and contact activation system (kinin system and coagulation system)], line II mediators (biologically active lipids) and line III mediators (cytokines) [32].

\section{당 infection and cytokines}

\section{Cytokines}

Cytokines are small protein molecules that regulate the 
cellular function of several immune cells. Their role has been evident in the defense against infectious agents, tumor cells and they are similarly involved in trauma, sepsis, and other immune responses. Particularly important is their involvement in the differentiation of T-cells and careful modulation of immune functions. Depending upon their target of action, function or which cell they are secreted from, they can be further classified into lymphokines, interleukins (ILs), monokines, IFNs, colony-stimulating factors, or chemokines [33]. Based on the response they exhibit from the immune cells they interact with, cytokines are regarded as pro-inflammatory or anti-inflammatory. Proper cell function is dependent on the balance between pro-inflammatory and anti-inflammatory cytokines. Cellular processes form an essential system that involves complicated signaling pathways and cascades of biochemical reactions. Such processes need to be tightly controlled, as disruption of established feedback mechanisms can lead to tissue damage. For instance, cytokine storms are known to occur in cases of overproduction, which, depending on their severity, can become life-threatening [34].

\section{TNF- $\alpha$}

One particular cytokine involved in $\mathrm{HCV}$ infections is TNF- $\alpha$, which activates fibroblasts and attracts them to the inflammatory site. Additionally, TNF- $\alpha$ plays a role in mediating the process of apoptosis and is capable of impeding tumor growth, inducing fever and even cachexia. It is produced mainly by activated macrophages and has a chemotactic effect on hepatocytes. It can facilitate leukocyte adhesion to targeted sites by way of engaging the expression of intracellular adhesion molecules (ICAMs), as well as integrins and selectins [35].

Hosomura et al. have shown that non-structural HCV proteins (NS3, NS4, NS5) play an important role in stimulating Kupffer cells (KCs) that will manufacture inflammatory cytokines like IL- $1 \beta$ and TNF- $\alpha$ [36]. Other studies have highlighted the correlation between elevated TNF- $\alpha$ concentrations with hepatic inflammation evaluated immunohistopathologically [histological activity index (HAI)] [37, 38], the association of increased TNF- $\alpha$ synthesis but accompanied by a decrease in IL-10 with severe liver damage and in patients with HCC [39], studies in which the role of the association between TNF- $\alpha$ and IL-6 with auto-antibodies [rheumatoid factor immunoglobulin $\mathrm{M}$ isotype (IgM-RF); antinuclear auto-antibodies (ANA); anti-cardiolipin immunoglobulin $\mathrm{G}$ isotype (IgG anti-aCL); anti-cyclic citrullinated peptide (CCP) antibodies immunoglobulin $\mathrm{G}$ isotype (IgG anti-CCP)] was studied, as to distinguish between patients having true early rheumatoid arthritis and HCV-related arthropathy [40 43], or in HCV patients, steatosis and obesity, which are associated with elevated serum concentrations of TNF- $\alpha$ and IL-6 [44].

\section{IFN- $Y$}

In contrast, activated NK cells and T-lymphocytes produce IFN- $\gamma$, a cytokine which is an important regulator of both innate and adaptive immunity in HCV infection. In response to virus-infected cells, NK cells interact with plasmacytoid dendritic cells (pDCs) and monocytes to produce IFN- $\gamma[45]$.
However, when it comes to the treatment of patients with chronic $\mathrm{HCV}$, the initial pan-genotypic therapeutic option was IFN- $\alpha$, which demonstrated a sustained virological response rate of $8 \%$ up to $21 \%$ [46]. A significantly elevated level of IFN- $\gamma$, along with an increase in monocyte chemoattractant protein-1 (MCP-1) and IL-18, were highlighted in plasma harvested from humanized mouse model (HIL) infected with an HCV dose of $10^{7}$ focus-forming units (FFU)/mL at $27 \pm 8$ weeks after infection [47]. Similar findings to those reported in mice were also found in other studies in HCV infected individuals, the authors also mentioning that these three soluble proteins are involved in mediating the functions of macrophages and T-cells during HCV infection [48-51]. In other studies, blocking of IL-10 or TGF- $\beta$ synthesis was attempted and it was observed that this inhibition is followed by activation and proliferation of T-cells involved in HCV pathophysiology and increased IFN- $\gamma$ synthesis $[32,52-$ 55].

\section{Interleukins}

The human genome encodes for roughly 50 ILs and analogous proteins, of which there are fifteen commonly known but distinctive types designated numerically. While a small subset is synthesized by macrophages, monocytes and endothelial cells, most ILs are generated by Th CD4+ lymphocyte subpopulations and they are not stored within cells. They are secreted swiftly, and briefly in response to triggers such as infectious agents. Post-synthesis they travel to each target cell and bind to specific receptors located on the surface, modulating cellular behavior as a result. ILs bolster the differentiation and growth of Blymphocytes, T-lymphocytes, as well as hematopoietic cells [56].

\section{$I L-1 \alpha$ and IL-1 $\beta$}

IL-1 is an acute-phase protein and potent inflammatory cytokine produced locally by activated macrophages in response to various infections. B-lymphocytes, endothelium cells, fibroblasts, and astrocytes may also secrete IL-1, leading to a broad spectrum of biological functions in different tissues. IL-1 regulates diverse cellular processes during both acute and chronic infections, causing lymphocyte activation of CD4+ T-cells, B-cells and NK cells, neutrophil recruitment and subsequently enhancing phagocytosis. It can bring about an increased leukocyte/endothelial adhesion to the inflammatory focus [selectins, integrins, and intercellular adhesion molecules (ICAMs)] along with acute-phase proteins released by the liver. IL-1 stimulates the hypothalamic center of thermoregulation, thereby inducing a fever [12].

Additionally, it can exhibit chemotactic and activating effects on pro-inflammatory cells; it encourages the production of platelet aggregating factors, synthesis of von Willebrand factor, as well as attracting and increasing the activity of fibroblasts [56]. Furthermore, IL-1 contributes to myeloid cell differentiation through an increase in the expression of growth factors, specifically: granulocyte colony-stimulating factor (G-CSF), as well as granulocyte/ macrophage colony-stimulating factor (GM-CSF). Beyond these, worth mentioning is its involvement in DC maturation and differentiation of T-helper type 17 (Th17) [57]. 
Defined as having two isoforms, IL- $1 \alpha$ and IL- $1 \beta$, both forms of IL-1 share the same IL-1 receptor type 1 (IL-1R1), which is expressed on specific cell types [58, 59]. IL- $1 \alpha$ and IL-33 are cytokines that perform two functions, they bind to each's specific cell surface receptor and their intracellular precursor forms ultimately end up translocating to the nucleus in order to modulate the transcription of pro-inflammatory genes [60]. However, in order for IL- $1 \beta$ to reach its mature form, its precursor (pro-IL-1 $\beta$ ) needs to be cleaved by cytosolic caspase-1. One study suggests that inhibition of inflammasome complex assembly using small interfering RNA (siRNA) against NLRP3, ASC or caspase-1 may lead to a reduction in the secretion of IL- $1 \beta$ by HCV-infected cells [9].

\section{IL-6}

In the liver, IL-6 is produced chiefly by KCs, subsequently enhancing the production of several acute-phase proteins, such as C-reactive protein, fibrinogen, haptoglobin, serum amyloid A, as well as others. One study suggests that the IL-6/signal transducer and activator of the transcription 3 (IL-6/STAT3) signaling pathway has a noteworthy inducible effect on micro-RNA-125b ( $m i R$ 125b) gene expression and that STAT3 and siRNA or inhibitor may diminish the replication of HCV. Previously, $m i R-125 b$ had been shown to regulate inflammation, as well as act as an oncogene pertaining to several cancer types [61]. Furthermore, increased production of IL-6 through the stimulation of TLR2 by HCV core protein may have a key role in the pathogenesis of B-cell nonHodgkin's lymphoma (B-NHL) and hepatitis C-associated mixed cryoglobulinemia (MC). When viral antigens stimulate the host's inflammatory response through extracellular PRRs, they likely promote the development of $\mathrm{MC}$ and $\mathrm{B}-\mathrm{NHL}$ in patients with chronic $\mathrm{HCV}$ [62].

As both a pro-inflammatory cytokine, as well as an anti-inflammatory myokine, IL-6 is synthesized by T- and B-lymphocytes, fibroblasts, endothelial cells, keratinocytes, synoviocytes, chondrocytes and epithelial cells in response to bacterial and viral infections, inflammation or trauma, with swift detectable plasma levels. Not only is it involved in the growth and differentiation of B-cells but it also stimulates Ig production, as well as hematopoiesis by acting synergistically with IL-3. Last but not least, it can induce adrenocorticotropic hormone (ACTH) secretion and other pituitary hormones, such as growth hormone, luteinizing hormone and prolactin [63].

Its role as an anti-inflammatory myokine is brought about through its inhibitory effects on IL- 1 and TNF- $\alpha$, along with the activation of IL-10 and IL-1 receptor antagonists (IL-1ra). IL-6 is a pleiotropic cytokine consisting of 184 amino acids, with a molecular weight of about $21 \mathrm{kDa}$, depending on the degree of glycosylation, playing a vital role in priming T-cell growth, influencing their differentiation and inhibiting the apoptosis of lymphocytes. It is recognized as a marker of the host inflammatory response and a mediator of both innate and cell-mediated immunity. Moreover, it acts as a promoter for the differentiation of Th17-cells, which secrete IL-17 [64].

Albumin and transferrin synthesis in the liver are both decreased following exposure to IL-6, hepatocyte regeneration processes being opted for instead [65].
Nevertheless, following HCV infection, patients who show compellingly higher than average levels of IL-6, appear to respond poorly to antiviral therapy $[48,66,67]$. The use of IL-6 and IL-10 as biomarkers may be appropriate for early $\mathrm{CHC}$ detection. While being involved in our body's immune response, IL-6 has a further protective role through the enhancement of lymphocyte effector functions, hence being of use along with other factors in $\mathrm{T}$-cell immunotherapy for those suffering from chronic HCV infection [68].

\section{IL-28}

Synthesized by regulatory T-cells (also known as "Tregs"), IL-28 stimulates cell presentation of viral antigens to CD8+-type T-lymphocytes, as well as upregulating TLR-2 and TLR-3 expression. TLRs are known to be involved in innate immunity and they interact with different antigens according to their subtype [69]. Of note, TLR-3 can recognize double-stranded RNA (dsRNA) and subsequently initiate the production of type 1 IFN. It has been recently shown that a specific polymorphism (rs12979860) near the $I L-28 B$ gene has been correlated with a heightened response to treatment with IFN and Ribavirin in $\mathrm{HCV}$-infected patients. This specific polymorphism has also been associated with interferon-lambda 4 (IFN- $\lambda 4$ ) protein, which may have a role in clearing $\mathrm{HCV}[70,71]$.

It is known that IL-28A or IFN- $\lambda 2$ and IFN- $\lambda 3$, formerly known as IL-28B, along with IL-29 or IFN- $\lambda 1$ are three cytokines that are part of type III IFNs, IFN- $\lambda[72,73]$.

Dolganiuc et al. have obtained elevated serum concentrations of IL-28A and IL-29 in patients with chronic $\mathrm{HCV}$, but also in the liver [elevated messenger RNA (mRNA) levels of IL-28 and IL-29, but also receptors expression], which may indicate that chronic inflammation of the liver would be produced by a double pathophysiological mechanism, by the action of the virus and by the immune response to the virus. In the experiments performed, it has been shown that DCs exposure to IFN- $\lambda$ is followed by inhibition of IL-12 synthesis but not IL-2 production, suggesting an immunomodulatory effect of IFN $-\lambda$ on DC and T-cells [74]. These results are in line with other studies previously published but it also denies the results of other studies [75-79].

\section{IL-22}

IL-22, a cytokine belonging to the IL-10 family, is comprised of eight other soluble proteins (IL-28A, IL-28B, IL-29, IL-10, IL-19, IL-20, as well as IL-24) [80]. There is evidence to suggest that the IL-22 specific receptor cannot be highlighted in immune cells with immune mediation functions, but it can only be expressed on liver cells, epithelial cells that paste the gastrointestinal tract, in the skin and lung (territories where IL-22 implicitly exerts its effects, namely regulating inflammation of the local tissue) [81, 82].

Th17 lymphocyte has been found to synthesize IL-22, in addition to the IL-17A and IL-17F cytokines [83], but it was found that IL-22 is synthesized by gamma/delta T $(\gamma / \lambda \mathrm{T})$ cell lymphocytes subpopulations [84] and innate lymphoid cells (ILCs, lymphoid cells of innate immunity considered to be the newest members of the lymphoid line; three groups were described, such as group $1 / \mathrm{ILC} 1 \mathrm{~s}$, repre- 
sented by NK cells, group 2/ILC2s, which synthesizes IL-5 and IL-13, playing an essential role in the immune response to helminth infections, group 3/ILC3s, originally described as intestinal lymphoid cells with a role in activating NK cells) $[85,86]$.

Sabat et al. observed that increased IL-22 concentrations and its inhibitor IL-22 binding protein (IL-22BP) in cultures highlights a significant correspondence with protection from hepatic fibrosis along with portal hypertension in patients with chronic HCV infection, thus having a key role in hepatic regeneration through the proliferation of hepatocytes and their migration [87].

Eyerich et al. have described a novel set of Th lymphocytes other than Th1, Th2, Th17 or other T-lymphocytes known to date, in the studies performed to the patients with inflammatory skin diseases (atopic dermatitis, contact dermatitis, epithelial hyperplasia of psoriasis), a subset named Th22, a unique subset that can mediate skin inflammatory processes, a new set that may be a target in the future for therapeutic intervention [88, 89].

\section{IL-27}

IL-27 is regarded as a pro-inflammatory cytokine and being part of the IL-6/IL-12 family, it mediates the activity of T-cells and implicitly participates to coordinate the activity of the cells involved in the innate immune response. Studies performed in vitro, have shown that IL-27 has biological effects, for example, the stimulation of CD4+ Th-lymphocytes and IL-12 stimulates the activation of mouse native cells, initiation of Th1 differentiation and proliferation, the activation of innate immune cells and release of IFN- $\gamma$ [90].

It has been found that the IL-27 specific receptor, consisting of two signal molecules (IL-27R $\alpha$ and gp130) is found in the immune cells involved in both the innate immune response and those involved in the adaptive response [91]. Also, there are studies, that have highlighted as IL-27 acts like IFN, having antiviral activity inhibiting HCV replication [92, 93].

\section{IL-10 and IL-12}

IL-10 is released by several immune cells, as they are Th2-lymphocytes, B-cells and macrophages [94]. IL-12 is a potent cytokine with pro-inflammatory action, synthesized especially by antigen-presenting cells after they are stimulated by IFN- $\gamma$ [10]. It is an important factor involved in differentiating naïve T-cells into Th1- and Th2-cells, a potent modulator of both immune, innate and adaptive responses $[95,96]$. In several studies, elevated serum concentrations of IL-10 and IL-12 were obtained in patients with chronic $\mathrm{HCV}$ with statistical significance, values associated with the degree of an inflammatory process or have statistically positive correlations with HCV progression [97-102].

\section{IL-35}

IL-35 has recently emerged as a novel immunosuppressive and anti-inflammatory cytokine secreted by regulatory T-cells, regulatory B-cells, DC and to a lesser extent by monocytes, endothelial cells and smooth muscle cells [103]. A recent study demonstrated how serum IL-35 levels can be elevated in patients with $\mathrm{CHC}$ and how IL-35 stimulation may reduce inflammatory cytokine production by the liver through STAT1/3 inhibitions. Moreover, the overall level of "Tregs" became elevated due to IL-35 stimulation, and this stimulation likewise inhibited cellular proliferation and increased the making of anti-inflammatory cytokines, such as IL-10 [104].

\section{IL-17}

Several types of Th-cells have crucial functions following activation; the subtype Th17-cells, a subset of CD4+ Tcells, are notably increased in HCV infection, being involved in its progression to chronicity. Th17-cells increase the inflammation of the liver and release pro-inflammatory cytokines, such as IL-17A, IL-17F, IL-21, and IL-22, because of stimulating the differentiation and expansion of Th17-cells by IL-1, IL-6, IL-23 or TNF- $\alpha$ [57, 64, 83]. On the other hand, IL-23, which is part of the IL-12 family, is essential for the survival as well as the extension of the Th17 population along with their inflammatory consequences $[105,106]$.

More recently, it was demonstrated that IL-23 and IL-17 (IL-23/Th17 axis) are the pivotal cytokines implicated in the immune as well as the inflammatory reaction pertaining to chronic liver diseases [107]. It was also observed that an imbalance between "Tregs" and Th17cells regulates the immune response during antiviral treatment [108, 109]. Regarding IL-21, a recent report, published in 2018, reported that higher levels are predictors of sustained virological response in patients with HCV [6].

\section{ㅁ CHC infection and inflammasomes}

\section{Cysteine-dependent aspartate-directed protease-1 (caspase-1)}

The caspase-1, also known as IL-1-converting enzyme (ICE), is an enzyme initially synthesized as an inactive zymogen (pro-caspase-1). This enzyme becomes the active form when it is assembled within inflammasomes complex, when it has the role of mediating the transformation of cytokine precursors for IL- $1 \beta$, as well as IL-18 (pro-IL-1 $\beta$ and pro-IL-18), into intensely involved active forms in initiating immune mechanisms [9].

Activation of IL- $1 \beta$ and IL-18 will lead to differentiation of Th-lymphocytes in Th1 and Th17 populations, intensely involved in adaptive immune defense mechanisms. Compared to other cytokines, in which the regulation is done at transcriptional level, in the case of these two cytokines (IL-1 $\beta$ and IL-18) the synthesis takes place by stimulating the TLR or RLR receptors, with the synthesis of inactive forms. The final step of the synthesis is post-activation of inflammasomes mediated by NLR receptors [110-112].

\section{Inflammasomes}

Inflammasomes are considered protein complexes, at the cytosolic level, activated in various situations to which the host organism is subjected, e.g., metabolic disorders following stress or infectious processes [113, 114].

Studies have shown that several viruses, as they are hepatitis viruses (hepatitis B virus, HCV) [9, 115], respiratory tropism viruses (influenza A virus, respiratory syncytial virus) [116-118], deoxyribonucleic acid (DNA) viruses (herpes viruses, such as Herpes simplex virus 1; varicella- 
zoster virus) [119, 120], Vaccinia virus [121], human papillomavirus [122], have an important role in activation the inflammasomes, launching the aforementioned signaling cascade [123].

Regarding the structure of these complexes, a ring disposition was observed composed of three binding elements: NLR proteins [actively involved in inflammatory processes being the isotypes NLRP1, NLRP3, NLRP6 and NLR containing CARD domain, proteins 4 and 5 (NLRC4 and NLRC5)], ASC and caspase-1 (in some cases caspase-5 may be included) [124]. Depending on the NLRs or RLRs receptors that are included in the annular structure of the complex, four types of inflammasomes are known: NLRP3 inflammasome, inflammasome absent in melanoma 2 (AIM2), RIG-I inflammasome and $\gamma$-IFNinducible protein 16 (IFI16) inflammasome. Of these types, it has been observed that the first three forms, NLRP3, AIM2 and RIG-I, are mainly involved in viral infections [125].

The HCV RNA-induced IL- $1 \beta$ secretion is thought to be dependent upon the participation of inflammasome units like NLRP3, ASC, as well as caspase-1. Production and activation of IL-1 $\beta$ and IL-18 as pro-inflammatory cytokines swiftly follows $[125,126]$.

\section{Nucleotide-binding domain}

and NLRP3 inflammasome

The NLRP3 inflammasome complex has recently received the attention of researchers. The most important agonists of this complex that induce its formation have been identified as viruses, both liver viruses and viruses with respiratory tropism, but bacterial or fungal causes should not be excluded. Ulland et al. have shown that the NLRP3 inflammasome can be activated by various bacterial pathogens, such as lipopolysaccharides, bacterial endotoxins, but also bacterial RNA [111, 112]. Due to the role that these inflammasomes have in sustaining our immunity, several viruses encode for proteins which can assist in blocking their specific pathway, therefore preventing IL- $1 \beta$ production or halting the activation of caspase-1 [125].

The structure of NLRP3 respects the ring, tripartite, typical arrangement of inflammasomes: a pyrin and PYCARD, NOD domain and a C-terminal-leucine-rich repeats (LRRs) domain [126]. This structure will form the basis of the formation of inflammatory complexes. During inflammatory processes, after these complexes of inflammasomes are formed, they become active and able to enzymatically activate caspase- 1 and the cascade of reactions culminates with the release of mature and active cytokines, IL- $1 \beta$ and IL-18, respectively [113, 126-128].

Burdette et al. have been highlighted the novel induction, as well as the assembly of the NALP3 inflammasome complex, in human hepatoma cells that had been infected with HCV (using mock-infected and HCV-infected Huh 7.5 cells) followed by IL- $1 \beta$ synthesis, as a result of a proteolytic process of activating pro-caspase- 1 and turning it into mature caspase-1 [9]. Also, authors have noticed an inhibition (using ROS inhibitor Diphenyleneiodonium) of only $60 \%$ of IL- $1 \beta$ secretion in HCV-infected cells incubated with Pyrrolidine Dithiocarbamate (PDTC), thus demonstrating the involvement of ROS in the induction of inflammasome complex assembly and stimulate IL- $1 \beta$ secretion, respectively [9, 10, 129].
In another study, it was intended to evaluate the involvement of various inflammasomes in liver cells, using experimental models of acute and chronic inflammation of the liver. It was observed that inflammasomes, such as NLRP-1, NLRP-3, and AIM2, were predominantly revealed at the level of $\mathrm{KCs}$ and in epithelial cells from the sinusoids, less expressed in peripheral myofibroblasts and hepatic stellate cells (HSCs) and very important these inflammasomes have not been highlighted in hepatocyte cultures. It has also been demonstrated in vitro that the stimulation with lipopolysaccharide (LPS) of cell cultures containing HSCs was followed after a while of a strong NLRP3 expression in hepatocytes [130].

Two different studies were published and have reported that hepatocytes are activated and express inflammasome complex but do not stimulate the sufficient synthesis of IL- $1 \beta$ and IL-18 $[131,132]$. Other studies support the production of ROS as a result of HCV stimulation induced by NLRP3 inflammasome complex assembly, along with the activation of a specific pathway, named the nuclear factor-kappa $\mathrm{B}(\mathrm{NF}-\kappa \mathrm{B})$ pathway and production of IL- $1 \beta$ and IL-18 cytokines $[51,133]$. Additionally, Guarda et al. have shown that treatment with type I IFN (IFN- $\alpha$ and IFN- $\beta$ ) inhibits the activity of NLRP1b and NLRP3 inflammasomes, which will not trigger the activation of the caspase- 1 enzyme and thus IL- $1 \beta$ maturation does not occur [134].

All these results obtained in many studies, over the past two decades, show that NLRP3 inflammasome complex or IL- $1 \beta$ may constitute new therapeutic targets, in an attempt to get better management of chronic $\mathrm{HCV}$ infections.

\section{ㅁ Conclusions}

In this brief review, we have attempted to highlight the fact that the inflammatory process triggered by HCV infection is the result of several mechanisms, such as the recognition of HCV RNA and viral protein components by immune cells belonging to both innate and acquired immunity, a second mechanism being the excessive synthesis of numerous pro-inflammatory and anti-inflammatory cytokines, chemokines, adipocytokines, activating the assembly of inflammasomes complex, mechanisms to which are added the action of ROS, as finally on a global basis to influence both the local inflammatory response (at the level of the hepatocyte, where viral replication occurs), as well as systemic inflammation. Also, these structures, immune cells or inflammasomes, involved in these mechanisms may constitute new therapeutic targets, to ameliorate the damage to the liver micromedium and prevent the occurrence of irreversible liver tissue injuries.

\section{Conflict of interests}

The authors declare that they have no conflict of interests.

\section{Authors' contribution}

Anca Marilena Ungureanu and Mihail Virgil Boldeanu equally contributed to the manuscript.

\section{References}

[1] Brunt EM. Nonalcoholic steatohepatitis. Semin Liver Dis, 2004, 24(1):3-20. https://doi.org/10.1055/s-2004-823098 PMID: 15085483 
[2] World Health Organization (WHO). Global hepatitis report 2017 License: CC BY-NC-SA 3.0 IGO, WHO, Geneva, Switzerland, 2017, https://apps.who.int/iris/bitstream/handle/10665/255016/ 9789241565455-eng.pdf?sequence=1\&isAllowed=y.

[3] Grigorescu M; Romanian Society of Gastroenterology and Hepatology. HCV genotype 1 is almost exclusively present in Romanian patients with chronic hepatitis C. J Gastrointestin Liver Dis, 2009, 18(1):45-50. PMID: 19337633

[4] Gower E, Estes C, Blach S, Razavi-Shearer K, Razavi H Global epidemiology and genotype distribution of the hepatitis C virus infection. J Hepatol, 2014, 61(1 Suppl):S45-S57. https://doi.org/10.1016/j.jhep.2014.07.027 PMID: 25086286

[5] National Institutes of Health. National Institutes of Health Consensus Development Conference Statement: Management of hepatitis C: 2002 - June 10-12, 2002. Hepatology, 2002, 36(5 Suppl 1):S3-S20. https://doi.org/10.1053/jhep.2002.37 117 PMID: 12407572

[6] Ragab HM, El Maksoud NA, Amin MA, Halim MH, Abdulla NA Kamel A, Moussa SM. IL-21 as a predictor of sustained virologic response in patients with chronic hepatitis $C$ virus infection. Appl Biochem Biotechnol, 2018, 185(2):484-493. https://doi. org/10.1007/s12010-017-2669-z PMID: 29192391

[7] Del Campo JA, Gallego P, Grande L. Role of inflammatory response in liver diseases: therapeutic strategies. World $\mathrm{J}$ Hepatol, 2018, 10(1):1-7. https://doi.org/10.4254/wjh.v10.i1.1 PMID: 29399273 PMCID: PMC5787673

[8] Martinon F, Burns K, Tschopp J. The inflammasome: a molecular platform triggering activation of inflammatory caspases and processing of prolL-beta. Mol Cell, 2002, 10(2):417-426. https://doi.org/10.1016/s1097-2765(02)00599-3 PMID: 12191486

[9] Burdette D, Haskett A, Presser L, McRae S, lqbal J, Waris G. Hepatitis $C$ virus activates interleukin- $1 \beta$ via caspase-1inflammasome complex. J Gen Virol, 2012, 93(Pt 2):235-246. https://doi.org/10.1099/vir.0.034033-0 PMID: 21994322 PMCID: PMC3352344

[10] Negash AA, Ramos HJ, Crochet N, Lau DTY, Doehle B, Papic N, Delker DA, Jo J, Bertoletti A, Hagedorn CH, Gale M Jr. IL-1 $\beta$ production through the NLRP3 inflammasome by hepatic macrophages links hepatitis $C$ virus infection with liver inflammation and disease. PLoS Pathog, 2013, 9(4):e1003330. https://doi.org/10.1371/journal.ppat.1003330 PMID: 23633957 PMCID: PMC3635973

[11] Ozaki E, Campbell M, Doyle SL. Targeting the NLRP3 inflammasome in chronic inflammatory diseases: current perspectives. J Inflamm Res, 2015, 8:15-27. https://doi.org/ 10.2147/JIR.S51250 PMID: 25653548 PMCID: PMC4303395

[12] Kasprzak A, Zabel M, Biczysko W, Wysocki J, Adamek A, Spachacz R, Surdyk-Zasada J. Expression of cytokines (TNF-alpha, IL-1alpha, and IL-2) in chronic hepatitis C: comparative hybridocytochemical and immunocytochemical study in children and adult patients. J Histochem Cytochem 2004, 52(1):29-38. https://doi.org/10.1177/002215540405200 104 PMID: 14688215

[13] Cheent K, Khakoo SI. Natural killer cells and hepatitis C: action and reaction. Gut, 2011, 60(2):268-278. https://doi. org/10.1136/gut.2010.212555 PMID: 20876777

[14] Borden EC, Sen GC, Uze G, Silverman RH, Ransohoff RM Foster GR, Stark GR. Interferons at age 50: past, current and future impact on biomedicine. Nat Rev Drug Discov, 2007, 6(12):975-990. https://doi.org/10.1038/nrd2422 PMID: 18049472 PMCID: PMC7097588

[15] Stetson DB, Medzhitov R. Type I interferons in host defense. Immunity, 2006, 25(3):373-381. https://doi.org/10.1016/j.immuni. 2006.08.007 PMID: 16979569

[16] Vidal SM, Khakoo SI, Biron CA. Natural killer cell responses during viral infections: flexibility and conditioning of innate immunity by experience. Curr Opin Virol, 2011, 1(6):497-512. https://doi.org/10.1016/j.coviro.2011.10.017 PMID: 22180766 PMCID: PMC3237675

[17] Moretta A. Natural killer cells and dendritic cells: rendezvous in abused tissues. Nat Rev Immunol, 2002, 2(12):957-964. https://doi.org/10.1038/nri956 PMID: 12461568

[18] Marcenaro E, Della Chiesa M, Bellora F, Parolini S, Millo R, Moretta L, Moretta A. IL-12 or IL-4 prime human NK cells to mediate functionally divergent interactions with dendritic cells or tumors. J Immunol, 2005, 174(7):3992-3998. https://doi.org/ 10.4049/jimmunol.174.7.3992 PMID: 15778356
[19] Smith CW. 3. Adhesion molecules and receptors. J Allergy Clin Immunol, 2008, 121(2 Suppl):S375-S379; quiz S414. https://doi.org/10.1016/j.jaci.2007.07.030 PMID: 18241685

[20] Banchereau J, Briere F, Caux C, Davoust J, Lebecque S, Liu YJ, Pulendran B, Palucka K. Immunobiology of dendritic cells. Annu Rev Immunol, 2000, 18:767-811. https://doi.org/ 10.1146/annurev.immunol.18.1.767 PMID: 10837075

[21] Brownlie RJ, Zamoyska R. T cell receptor signalling networks: branched, diversified and bounded. Nat Rev Immunol, 2013, 13(4):257-269. https://doi.org/10.1038/nri3403 PMID: 23524462

[22] Lauer GM, Barnes E, Lucas M, Timm J, Ouchi K, Kim AY, Day CL, Robbins GK, Casson DR, Reiser M, Dusheiko G, Allen TM, Chung RT, Walker BD, Klenerman P. High resolution analysis of cellular immune responses in resolved and persistent hepatitis C virus infection. Gastroenterology, 2004, 127(3):924-936. https://doi.org/10.1053/j.gastro.2004.06.015 PMID: 15362047

[23] Prystowsky MB, Ely JM, Beller DI, Eisenberg L, Goldman J, Goldman M, Goldwasser E, Ihle J, Quintans J, Remold H, Vogel SN, Fitch FW. Alloreactive cloned T cell lines. VI. Multiple lymphokine activities secreted by helper and cytolytic cloned T Iymphocytes. J Immunol, 1982, 129(6):2337-2344. PMID: 6216281

[24] Fong TA, Mosmann TR. Alloreactive murine CD8+ T cell clones secrete the Th1 pattern of cytokines. J Immunol, 1990, 144(5):1744-1752. PMID: 2137843

[25] Moser M, Murphy KM. Dendritic cell regulation of TH1-TH2 development. Nat Immunol, 2000, 1(3):199-205. https://doi. org/10.1038/79734 PMID: 10973276

[26] Pestka S, Krause CD, Sarkar D, Walter MR, Shi Y, Fisher PB. Interleukin-10 and related cytokines and receptors. Annu Rev Immunol, 2004, 22:929-979. https://doi.org/10.1146/annurev. immunol.22.012703.104622 PMID: 15032600

[27] Tinoco R, Alcalde V, Yang Y, Sauer K, Zuniga El. Cellintrinsic transforming growth factor- $\beta$ signaling mediates virusspecific $\mathrm{CD}^{+} \mathrm{T}$ cell deletion and viral persistence in vivo. Immunity, 2009, 31(1):145-157. https://doi.org/10.1016/j.immuni. 2009.06.015 PMID: 19604493 PMCID: PMC3039716

[28] Penin F, Dubuisson J, Rey FA, Moradpour D, Pawlotsky JM Structural biology of hepatitis C virus. Hepatology, 2004, 39(1):5-19. https://doi.org/10.1002/hep.20032 PMID: 14752815

[29] Waggoner SN, Hall CHT, Hahn YS. HCV core protein interaction with $\mathrm{gC} 1 \mathrm{q}$ receptor inhibits Th1 differentiation of CD4+ $\mathrm{T}$ cells via suppression of dendritic cell $\mathrm{IL}-12$ production. J Leukoc Biol, 2007, 82(6):1407-1419. https://doi.org/10.1189/ jlb.0507268 PMID: 17881511

[30] Kittlesen DJ, Chianese-Bullock KA, Yao ZQ, Braciale TJ, Hahn YS. Interaction between complement receptor gC1qR and hepatitis $\mathrm{C}$ virus core protein inhibits T-lymphocyte proliferation. J Clin Invest, 2000, 106(10):1239-1249. https://doi. org/10.1172/JCI10323 PMID: 11086025 PMCID: PMC381434

[31] Brady MT, MacDonald AJ, Rowan AG, Mills KHG. Hepatitis C virus non-structural protein 4 suppresses Th1 responses by stimulating IL-10 production from monocytes. Eur J Immunol, 2003, 33(12):3448-3457. https://doi.org/10.1002/eji.200324251 PMID: 14635055

[32] Heim MH, Thimme R. Innate and adaptive immune responses in HCV infections. J Hepatol, 2014, 61(1 Suppl):S14-S25. https://doi.org/10.1016/j.jhep.2014.06.035 PMID: 25443342

[33] Bertoletti A, D'Elios MM, Boni C, De Carli M, Zignego AL, Durazzo M, Missale G, Penna A, Fiaccadori F, Del Prete G, Ferrari C. Different cytokine profiles of intrahepatic $T$ cells in chronic hepatitis B and hepatitis C virus infections. Gastroenterology, 1997, 112(1):193-199. https://doi.org/10.1016/ s0016-5085(97)70235-x PMID: 8978359

[34] Bohmwald K, Gálvez NMS, Canedo-Marroquín G, PizarroOrtega MS, Andrade-Parra C, Gómez-Santander F, Kalergis AM. Contribution of cytokines to tissue damage during human respiratory syncytial virus infection. Front Immunol, 2019, 10:452. https://doi.org/10.3389/fimmu.2019.00452 PMID: 30936869 PMCID: PMC6431622

[35] Lopetuso LR, Mocci G, Marzo M, D'Aversa F, Rapaccini GL, Guidi L, Armuzzi A, Gasbarrini A, Papa A. Harmful effects and potential benefits of anti-tumor necrosis factor (TNF)- $\alpha$ on the liver. Int J Mol Sci, 2018, 19(8):2199. https://doi.org/10. 3390/ijms19082199 PMID: 30060508 PMCID: PMC6121684

[36] Hosomura N, Kono H, Tsuchiya M, Ishii K, Ogiku M, Matsuda M, Fujii H. HCV-related proteins activate Kupffer cells isolated from human liver tissues. Dig Dis Sci, 2011, 56(4):1057-1064. https://doi.org/10.1007/s10620-010-1395-y PMID: 20848204 
[37] Neuman MG. Cytokines - central factors in alcoholic liver disease. Alcohol Res Health, 2003, 27(4):307-316. PMID: 15540802 PMCID: PMC6668870

[38] Neuman MG, Schmilovitz-Weiss H, Hilzenrat N, Bourliere M, Marcellin P, Trepo C, Mazulli T, Moussa G, Patel A, Baig AA, Cohen L. Markers of inflammation and fibrosis in alcoholic hepatitis and viral hepatitis C. Int J Hepatol, 2012, 2012 231210. https://doi.org/10.1155/2012/231210 PMID: 22530132 PMCID: PMC3296182

[39] Aroucha DCBL, do Carmo RF, Moura P, Silva JLA, Vasconcelos LRS, Cavalcanti MSM, Muniz MTC, Aroucha ML, Siqueira ERF, Cahú GGOM, Pereira LMMB, Coêlho MRCD. High tumor necrosis factor- $\alpha$ /interleukin-10 ratio is associated with hepatocellular carcinoma in patients with chronic hepatitis $\mathrm{C}$. Cytokine, 2013, 62(3):421-425. https://doi.org/10.1016/j.cyto. 2013.03.024 PMID: 23602201

[40] Siloşi I, Boldeanu L, Biciuşcă V, Bogdan M, Avramescu C, Taisescu C, Padureanu V, Boldeanu MV, Dricu A, Siloşi CA. Serum biomarkers for discrimination between hepatitis $\mathrm{C}$ related arthropathy and early rheumatoid arthritis. Int $\mathrm{J} \mathrm{Mol}$ Sci, 2017, 18(6):1304. https://doi.org/10.3390/ijms18061304 PMID: 28629188 PMCID: PMC5486125

[41] Siloşi CA, Siloşi I, Pădureanu V, Bogdan M, Mogoantă SŞ, Ciurea ME, Cojocaru M, Boldeanu L, Avrămescu CS, Boldeanu MV, Popa DG. Sepsis and identification of reliable biomarkers for postoperative period prognosis. Rom J Morphol Embryol, 2018, 59(1):77-91. PMID: 29940615

[42] Bogdan M, Silosi I, Surlin P, Tica AA, Tica OS, Balseanu TA, Rauten AM, Camen A. Salivary and serum biomarkers for the study of side effects of aripiprazole coprescribed with mirtazapine in rats. Int J Clin Exp Med, 2015, 8(5):8051-8059. PMID: 26221370 PMCID: PMC4509315

[43] Petrescu IO, Biciuşcă V, Taisescu Cl, Alexandru DO, Taisescu O, Comănescu MV, Petrescu F, Popescu IAS, Traşcă DM, Forţofoiu MC, Siloşi CA, Forţofoiu M. Histological factors that predict the liver fibrosis in patients with chronic hepatitis C. Rom J Morphol Embryol, 2016, 57(2 Suppl):759-765. PMID: 27833969

[44] Jonsson JR, Barrie HD, O'Rourke P, Clouston AD, Powell EE. Obesity and steatosis influence serum and hepatic inflammatory markers in chronic hepatitis C. Hepatology, 2008, 48(1):80-87. https://doi.org/10.1002/hep.22311 PMID: 18571785

[45] Zhang S, Saha B, Kodys K, Szabo G. IFN- $\gamma$ production by human natural killer cells in response to HCV-infected hepatoma cells is dependent on accessory cells. J Hepatol, 2013, 59(3): 442-449. https://doi.org/10.1016/j.jhep.2013.04.022 PMID: 23665181 PMCID: PMC3760030

[46] Bastos JCS, Padilla MA, Caserta LC, Miotto N, Vigani AG, Arns CW. Hepatitis $C$ virus: promising discoveries and new treatments. World J Gastroenterol, 2016, 22(28):6393-6401. https://doi.org/10.3748/wjg.v22.i28.6393 PMID: 27605875 PMCID: PMC4968121

[47] Zheng Z, Sze CW, Keng CT, Al-Haddawi M, Liu M, Tan SY, Kwek HL, Her Z, Chan XY, Barnwal B, Loh E, Chang KTE, Tan TC, Tan YJ, Chen Q. Hepatitis C virus mediated chronic inflammation and tumorigenesis in the humanized immune system and liver mouse model. PLoS One, 2017, 12(9): e0184127. https://doi.org/10.1371/journal.pone.0184127 PMID: 28886065 PMCID: PMC5590885

[48] Panasiuk A, Prokopowicz D, Panasiuk B. Monocyte chemotactic protein-1 and soluble adhesion molecules as possible prognostic markers of the efficacy of antiviral treatment in chronic hepatitis C. World J Gastroenterol, 2004, 10(24):36393642. https://doi.org/10.3748/wjg.v10.i24.3639 PMID: 15534921 PMCID: PMC4612007

[49] Zeremski M, Petrovic LM, Talal AH. The role of chemokines as inflammatory mediators in chronic hepatitis $C$ virus infection J Viral Hepat, 2007, 14(10):675-687. https://doi.org/10.1111/ j.1365-2893.2006.00838.x PMID: 17875002

[50] McGuinness PH, Painter D, Davies S, McCaughan GW. Increases in intrahepatic CD68 positive cells, MAC387 positive cells, and proinflammatory cytokines (particularly interleukin 18) in chronic hepatitis C infection. Gut, 2000, 46(2):260-269. https://doi.org/10.1136/gut.46.2.260 PMID: 10644323 PMCID: PMC1727823

[51] Shrivastava S, Mukherjee A, Ray R, Ray RB. Hepatitis C virus induces interleukin- $1 \beta$ (IL-1 $\beta$ )/IL-18 in circulatory and resident liver macrophages. J Virol, 2013, 87(22):12284-12290. https://doi.org/10.1128/JVI.01962-13 PMID: 24006444 PMCID: PMC3807883
[52] Cabrera R, Tu Z, Xu Y, Firpi RJ, Rosen HR, Liu C, Nelson DR. An immunomodulatory role for $\mathrm{CD} 4(+) \mathrm{CD} 25(+)$ regulatory $T$ lymphocytes in hepatitis C virus infection. Hepatology, 2004, 40(5):1062-1071. https://doi.org/10.1002/hep.20454 PMID: 15486925

[53] Accapezzato D, Francavilla V, Paroli M, Casciaro M, Chircu LV, Cividini A, Abrignani S, Mondelli MU, Barnaba V. Hepatic expansion of a virus-specific regulatory $\mathrm{CD} 8(+) \mathrm{T}$ cell population in chronic hepatitis $C$ virus infection. J Clin Invest, 2004, 113(7):963-972. https://doi.org/10.1172/JCl20515 PMID: 15057302 PMCID: PMC379326

[54] Rowan AG, Fletcher JM, Ryan EJ, Moran B, Hegarty JE, O'Farrelly C, Mills KHG. Hepatitis C virus-specific Th17 cells are suppressed by virus-induced TGF-beta. J Immunol, 2008, 181(7):4485-4494. https://doi.org/10.4049/jimmunol.181.7.4485 PMID: 18802051

[55] Kanto T, Takehara T, Katayama K, Ito A, Mochizuki K, Kuzushita N, Tatsumi T, Sasaki Y, Kasahara A, Hayashi N, Hori M. Neutralization of transforming growth factor beta 1 augments hepatitis C virus-specific cytotoxic T lymphocyte induction in vitro. J Clin Immunol, 1997, 17(6):462-471. https://doi.org/10.1023/a:1027367626317 PMID: 9418186

[56] Akdis M, Burgler S, Crameri R, Eiwegger T, Fujita H, Gomez E, Klunker S, Meyer N, O'Mahony L, Palomares O, Rhyner C, Ouaked N, Schaffartzik A, Van De Veen W, Zeller S, Zimmermann M, Akdis CA. Interleukins, from 1 to 37 , and interferon- $y$ : receptors, functions, and roles in diseases. J Allergy Clin Immunol, 2011, 127(3):701-721.e1-721.e70. https://doi.org/10.1016/j.jaci.2010.11.050 PMID: 21377040

[57] Dinarello CA. Interleukin-1 and the pathogenesis of the acutephase response. N Engl J Med, 1984, 311(22):1413-1418. https:// doi.org/10.1056/NEJM198411293112205 PMID: 6208485

[58] Copeland NG, Silan CM, Kingsley DM, Jenkins NA, Cannizzaro LA, Croce CM, Huebner K, Sims JE. Chromosomal location of murine and human IL-1 receptor genes. Genomics, 1991, 9(1): 44-50. https://doi.org/10.1016/0888-7543(91)90219-5 PMID: 1672292

[59] Dower SK, Qwarnstrom EE, Page RC, Blanton RA, Kupper TS, Raines E, Ross R, Sims JE. Biology of the interleukin-1 receptor. J Invest Dermatol, 1990, 94(6 Suppl):68S-73S. https:// doi.org/10.1111/1523-1747.ep12875154 PMID: 2141050

[60] Dinarello CA. Interleukin-1 in the pathogenesis and treatment of inflammatory diseases. Blood, 2011, 117(14):3720-3732. https://doi.org/10.1182/blood-2010-07-273417 PMID: 21304099 PMCID: PMC3083294

[61] Dai CY, Tsai YS, Chou WW, Liu T, Huang CF, Wang SC, Tsai PC, Yeh ML, Hsieh MY, Huang CI, Vanson Liu SY, Huang JF, Chuang WL, Yu ML. The IL-6/STAT3 pathway upregulates microRNA-125b expression in hepatitis $C$ virus infection. Oncotarget, 2018, 9(13):11291-11302. https://doi. org/10.18632/oncotarget.24129 PMID: 29541414 PMCID: PMC5834265

[62] Feldmann G, Nischalke HD, Nattermann J, Banas B, Berg T, Teschendorf C, Schmiegel W, Dührsen U, Halangk J, Iwan A, Sauerbruch T, Caselmann WH, Spengler U. Induction of interleukin- 6 by hepatitis $C$ virus core protein in hepatitis $C$ associated mixed cryoglobulinemia and B-cell non-Hodgkin's lymphoma. Clin Cancer Res, 2006, 12(15):4491-4498. https:// doi.org/10.1158/1078-0432.CCR-06-0154 PMID: 16899594

[63] Tanaka T, Narazaki M, Kishimoto T. IL-6 in inflammation, immunity, and disease. Cold Spring Harb Perspect Biol, 2014, 6(10):a016295. https://doi.org/10.1101/cshperspect.a016295 PMID: 25190079 PMCID: PMC4176007

[64] Yuk CM, Park HJ, Kwon BI, Lah SJ, Chang J, Kim JY, Lee KM, Park SH, Hong S, Lee SH. Basophil-derived IL-6 regulates TH17 cell differentiation and CD4 T cell immunity. Sci Rep, 2017, 7:41744. https://doi.org/10.1038/srep41744 PMID: 28134325 PMCID: PMC5278410

[65] Vettor R, Milan G, Rossato M, Federspil G. Review article: adipocytokines and insulin resistance. Aliment Pharmacol Ther, 2005, 22(Suppl 2):3-10. https://doi.org/10.1111/j.136 5-2036.2005.02587.x PMID: 16225463

[66] Neuman MG, Benhamou JP, Malkiewicz IM, Akremi R, Shear NH, Asselah T, Ibrahim A, Boyer N, Martinot-Peignoux M, Jacobson-Brown P, Katz GG, Le Breton V, Le Guludec G, Suneja A, Marcellin P. Cytokines as predictors for sustained response and as markers for immunomodulation in patients with chronic hepatitis C. Clin Biochem, 2001, 34(3):173-182. https://doi.org/10.1016/s0009-9120(01)00212-0 PMID: 11408014 
[67] Zhang Y, Guo D, Zhao Y, Chen X, Ma L, Jin Y, Yan H, Wu H, Wei $L$, Dong T, Chen $X$. The effect of cytokine profiles on the viral response to re-treatment in antiviral-experienced patients with chronic hepatitis C virus infection. Antiviral Res, 2011, 92(2):247-254. https://doi.org/10.1016/j.antiviral.2011.08.009 PMID: 21889543

[68] Naseem S, Manzoor S, Javed A, Abbas S. Interleukin-6 rescues lymphocyte from apoptosis and exhaustion induced by chronic hepatitis $\mathrm{C}$ virus infection. Viral Immunol, 2018, 31(9):624-631. https://doi.org/10.1089/vim.2018.0045 PMID: 30222516

[69] Sato K, Ishikawa T, Okumura A, Yamauchi T, Sato S, Ayada M, Matsumoto E, Hotta N, Oohashi T, Fukuzawa Y, Kakumu S. Expression of Toll-like receptors in chronic hepatitis $C$ virus infection. J Gastroenterol Hepatol, 2007, 22(10):1627-1632. https:// doi.org/10.1111/j.1440-1746.2006.04783.x PMID: 17845690

[70] Matsuura K, Watanabe T, Tanaka Y. Role of IL28B for chronic hepatitis $C$ treatment toward personalized medicine. J Gastroenterol Hepatol, 2014, 29(2):241-249. https://doi.org/10.1111/ jgh.12475 PMID: 24325405

[71] Ge D, Fellay J, Thompson AJ, Simon JS, Shianna KV, Urban TJ, Heinzen EL, Qiu P, Bertelsen AH, Muir AJ, Sulkowski M, McHutchison JG, Goldstein DB. Genetic variation in IL28B predicts hepatitis $C$ treatment-induced viral clearance. Nature 2009, 461(7262):399-401. https://doi.org/10.1038/nature08309 PMID: 19684573

[72] Kotenko SV, Gallagher G, Baurin VV, Lewis-Antes A, Shen M, Shah NK, Langer JA, Sheikh F, Dickensheets H, Donnelly RP. IFN-lambdas mediate antiviral protection through a distinct class II cytokine receptor complex. Nat Immunol, 2003, 4(1): 69-77. https://doi.org/10.1038/ni875 PMID: 12483210

[73] Sheppard P, Kindsvogel W, Xu W, Henderson K, Schlutsmeyer S, Whitmore TE, Kuestner R, Garrigues U, Birks C, Roraback J, Ostrander C, Dong D, Shin J, Presnell S, Fox B, Haldeman B, Cooper E, Taft D, Gilbert T, Grant FJ, Tackett M, Krivan W, McKnight G, Clegg C, Foster D, Klucher KM. IL-28, IL-29 and their class II cytokine receptor IL-28R. Nat Immunol, 2003, 4(1):63-68. https://doi.org/10.1038/ni873 PMID: 12469119

[74] Dolganiuc A, Kodys K, Marshall C, Saha B, Zhang S, Bala S, Szabo G. Type III interferons, IL-28 and IL-29, are increased in chronic HCV infection and induce myeloid dendritic cellmediated FoxP3+ regulatory T cells. PLoS One, 2012, 7(10): e44915. https://doi.org/10.1371/journal.pone.0044915 PMID: 23071503 PMCID: PMC3468613

[75] Boisvert M, Shoukry NH. Type III interferons in hepatitis C virus infection. Front Immunol, 2016, 7:628. https://doi.org/ 10.3389/fimmu.2016.00628 PMID: 28066437 PMCID: PMC 5179541

[76] Lee HC, Narayanan S, Park SJ, Seong SY, Hahn YS. Transcriptional regulation of IFN- $\lambda$ genes in hepatitis $C$ virusinfected hepatocytes via IRF-3•IRF-7•NF-kB complex. J Biol Chem, 2014, 289(8):5310-5319. https://doi.org/10.1074/jbc. M113.536102 PMID: 24385435 PMCID: PMC3931086

[77] Torres C, Brahm J, Venegas M. Lambda interferon serum levels in patients with chronic hepatitis $C$ virus infection according to their response to therapy with pegylated interferon and ribavirin. J Interferon Cytokine Res, 2014, 34(2):106-110. https://doi.org/10.1089/jir.2013.0005 PMID: 24070114

[78] Langhans B, Kupfer B, Braunschweiger I, Arndt S, Schulte W, Nischalke HD, Nattermann J, Oldenburg J, Sauerbruch T, Spengler U. Interferon-lambda serum levels in hepatitis C. J Hepatol, 2011, 54(5):859-865. https://doi.org/10.1016/j.jhep. 2010.08.020 PMID: 21145813

[79] Diegelmann J, Beigel F, Zitzmann K, Kaul A, Göke B, Auernhammer CJ, Bartenschlager R, Diepolder HM, Brand S. Comparative analysis of the lambda-interferons IL-28A and IL-29 regarding their transcriptome and their antiviral properties against hepatitis C virus. PLoS One, 2010, 5(12):e15200. https:// doi.org/10.1371/journal.pone.0015200 PMID: 21170333 PMCID: PMC2999541

[80] Wolk K, Kunz S, Witte E, Friedrich M, Asadullah K, Sabat R. IL-22 increases the innate immunity of tissues. Immunity, 2004, 21(2):241-254. https://doi.org/10.1016/j.immuni.2004. 07.007 PMID: 15308104

[81] Xie MH, Aggarwal S, Ho WH, Foster J, Zhang Z, Stinson J, Wood WI, Goddard AD, Gurney AL. Interleukin (IL)-22, a novel human cytokine that signals through the interferon receptorrelated proteins CRF2-4 and IL-22R. J Biol Chem, 2000,
275(40):31335-31339. https://doi.org/10.1074/jbc.M005304200 PMID: 10875937

[82] Lejeune D, Dumoutier L, Constantinescu S, Kruijer W, Schuringa JJ, Renauld JC. Interleukin-22 (IL-22) activates the JAK/STAT, ERK, JNK, and p38 MAP kinase pathways in a rat hepatoma cell line: pathways that are shared with and distinct from IL-10. J Biol Chem, 2002, 277(37):33676-33682. https://doi.org/10.1074/jbc.M204204200 PMID: 12087100

[83] Liang SC, Tan XY, Luxenberg DP, Karim R, DunussiJoannopoulos K, Collins M, Fouser LA. Interleukin (IL)-22 and IL-17 are coexpressed by Th17 cells and cooperatively enhance expression of antimicrobial peptides. J Exp Med, 2006, 203(10):2271-2279. https://doi.org/10.1084/jem.2006 1308 PMID: 16982811 PMCID: PMC2118116

[84] Martin B, Hirota K, Cua DJ, Stockinger B, Veldhoen M. Interleukin-17-producing $\gamma \delta$ T cells selectively expand in response to pathogen products and environmental signals. Immunity, 2009, 31(2):321-330. https://doi.org/10.1016/j.immuni. 2009.06.020 PMID: 19682928

[85] Walker JA, Barlow JL, McKenzie ANJ. Innate lymphoid cells - how did we miss them? Nat Rev Immunol, 2013, 13(2):7587. https://doi.org/10.1038/nri3349 PMID: 23292121

[86] Spits H, Cupedo T. Innate lymphoid cells: emerging insights in development, lineage relationships, and function. Annu Rev Immunol, 2012, 30:647-675. https://doi.org/10.1146/annurev -immunol-020711-075053 PMID: 22224763

[87] Sabat R, Ouyang W, Wolk K. Therapeutic opportunities of the IL-22-IL-22R1 system. Nat Rev Drug Discov, 2014, 13(1):2138. https://doi.org/10.1038/nrd4176 PMID: 24378801

[88] Eyerich S, Eyerich K, Pennino D, Carbone T, Nasorri F, Pallotta S, Cianfarani F, Odorisio T, Traidl-Hoffmann C, Behrendt H, Durham SR, Schmidt-Weber CB, Cavani A. Th22 cells represent a distinct human T cell subset involved in epidermal immunity and remodeling. J Clin Invest, 2009, 119(12):3573-3585. https://doi.org/10.1172/JCl40202 PMID: 19920355 PMCID: PMC2786807

[89] Trifari S, Kaplan CD, Tran EH, Crellin NK, Spits H. Identification of a human helper $\mathrm{T}$ cell population that has abundant production of interleukin 22 and is distinct from $\mathrm{T}(\mathrm{H})-17$, $\mathrm{T}(\mathrm{H}) 1$ and $\mathrm{T}(\mathrm{H}) 2$ cells. Nat Immunol, 2009, 10(8):864-871. https://doi.org/10.1038/ni.1770 PMID: 19578368

[90] Pflanz S, Timans JC, Cheung J, Rosales R, Kanzler H, Gilbert J, Hibbert L, Churakova T, Travis M, Vaisberg E, Blumenschein WM, Mattson JD, Wagner JL, To W, Zurawski S, McClanahan TK, Gorman DM, Bazan JF, de Waal Malefyt R, Rennick D, Kastelein RA. IL-27, a heterodimeric cytokine composed of EBI3 and p28 protein, induces proliferation of naive $\mathrm{CD}^{+} \mathrm{T}$ cells. Immunity, 2002, 16(6):779-790. https:// doi.org/10.1016/s1074-7613(02)00324-2 PMID: 12121660

[91] Morishima N, Mizoguchi I, Okumura M, Chiba Y, Xu M, Shimizu M, Matsui M, Mizuguchi J, Yoshimoto T. A pivotal role for interleukin-27 in CD8+ T cell functions and generation of cytotoxic T lymphocytes. J Biomed Biotechnol, 2010, 2010: 605483. https://doi.org/10.1155/2010/605483 PMID: 20454646 PMCID: PMC2862320

[92] Bender H, Wiesinger MY, Nordhoff C, Schoenherr C, Haan C, Ludwig S, Weiskirchen R, Kato N, Heinrich PC, Haan S. Interleukin-27 displays interferon- $y$-like functions in human hepatoma cells and hepatocytes. Hepatology, 2009, 50(2):585591. https://doi.org/10.1002/hep.22988 PMID: 19582813

[93] Frank AC, Zhang X, Katsounas A, Bharucha JP, Kottilil S, Imamichi T. Interleukin-27, an anti-HIV-1 cytokine, inhibits replication of hepatitis $C$ virus. J Interferon Cytokine Res, 2010, 30(6):427-431. https://doi.org/10.1089/jir.2009.0093 PMID: 20235668 PMCID: PMC2964364

[94] Naugler WE, Karin M. The wolf in sheep's clothing: the role of interleukin-6 in immunity, inflammation and cancer. Trends Mol Med, 2008, 14(3):109-119. https://doi.org/10.1016/j.mol med.2007.12.007 PMID: 18261959

[95] Del Vecchio M, Bajetta E, Canova S, Lotze MT, Wesa A, Parmiani G, Anichini A. Interleukin-12: biological properties and clinical application. Clin Cancer Res, 2007, 13(16):4677-4685. https://doi.org/10.1158/1078-0432.CCR-07-0776 PMID: 17699845

[96] Watford WT, Moriguchi M, Morinobu A, O'Shea JJ. The biology of IL-12: coordinating innate and adaptive immune responses. Cytokine Growth Factor Rev, 2003, 14(5):361-368. https://doi. org/10.1016/s1359-6101(03)00043-1 PMID: 12948519 
[97] Capone F, Costantini S, Guerriero E, Calemma R, Napolitano M Scala S, Izzo F, Castello G. Serum cytokine levels in patients with hepatocellular carcinoma. Eur Cytokine Netw, 2010, 21(2): 99-104. https://doi.org/10.1684/ecn.2010.0192 PMID: 20478763

[98] Kakumu S, Okumura A, Ishikawa T, Iwata K, Yano M, Yoshioka K. Production of interleukins 10 and 12 by peripheral blood mononuclear cells (PBMC) in chronic hepatitis $\mathrm{C}$ virus (HCV) infection. Clin Exp Immunol, 1997, 108(1):138-143. https://doi.org/10. 1046/j.1365-2249.1997.d01-987.x PMID: 9097922 PMCID: PMC1904630

[99] Sarih M, Bouchrit N, Benslimane A. Different cytokine profiles of peripheral blood mononuclear cells from patients with persistent and self-limited hepatitis $\mathrm{C}$ virus infection. Immunol Lett, 2000, 74(2):117-120. https://doi.org/10.1016/s0165-24 78(00)00210-8 PMID: 10996386

[100] Gigi E, Raptopoulou-Gigi M, Kalogeridis A, Masiou S, Orphanou E, Vrettou E, Lalla TH, Sinakos E, Tsapas V. Cytokine mRNA expression in hepatitis $C$ virus infection: TH1 predominance in patients with chronic hepatitis $\mathrm{C}$ and $\mathrm{TH} 1-\mathrm{TH} 2$ cytokine profile in subjects with self-limited disease. J Viral Hepat, 2008, 15(2):145-154. https://doi.org/10.1111/ j.1365-2893.2007.00908.x PMID: 18184198

[101] Taylor A, Verhagen J, Blaser K, Akdis M, Akdis CA. Mechanisms of immune suppression by interleukin-10 and transforming growth factor-beta: the role of $\mathrm{T}$ regulatory cells. Immunology, 2006, 117(4):433-442. https://doi.org/10.1111/ j.1365-2567.2006.02321.x PMID: 16556256 PMCID: PMC 1782242

[102] Liu G, Tang K, Li Q, Yuan G, Cao W, Lu W. Changes of IL-1, TNF-alpha, IL-12 and IL-10 levels with chronic liver failure. Surg Sci, 2011, 2(2):69-72. https://doi.org/10.4236/ ss.2011.22015

[103] Liu S, Zhang Q, Shao X, Wang W, Zhang C, Jin Z. An immunosuppressive function of interleukin-35 in chronic hepatitis C virus infection. Int Immunopharmacol, 2017, 50: 87-94. https://doi.org/10.1016/j.intimp.2017.06.015 PMID: 28644966

[104] Li X, Shao Y, Sha X, Fang P, Kuo YM, Andrews AJ, Li Y, Yang WY, Maddaloni M, Pascual DW, Luo JJ, Jiang X, Wang H, Yang X. IL-35 (interleukin-35) suppresses endothelial cell activation by inhibiting mitochondrial reactive oxygen species-mediated site-specific acetylation of H3K14 (histone 3 lysine 14). Arterioscler Thromb Vasc Biol, 2018, 38(3):599609. https://doi.org/10.1161/ATVBAHA.117.310626 PMID: 29371247 PMCID: PMC5823772

[105] Afford SC, Humphreys EH, Reid DT, Russell CL, Banz VM, Oo Y, Vo T, Jenne C, Adams DH, Eksteen B. Vascular cell adhesion molecule 1 expression by biliary epithelium promotes persistence of inflammation by inhibiting effector T-cell apoptosis. Hepatology, 2014, 59(5):1932-1943. https://doi. org/10.1002/hep.26965 PMID: 24338559

[106] Wilson NJ, Boniface K, Chan JR, McKenzie BS, Blumenschein WM, Mattson JD, Basham B, Smith K, Chen T, Morel F Lecron JC, Kastelein RA, Cua DJ, McClanahan TK, Bowman EP, de Waal Malefyt R. Development, cytokine profile, and function of human interleukin 17-producing helper T cells. Nat Immunol 2007, 8(9):950-957. https://doi.org/10.1038/ni1497 PMID: 17676044

[107] Meng P, Zhao S, Niu X, Fu N, Su S, Wang R, Zhang Y, Qiao L, Nan Y. Involvement of the interleukin-23/interleukin-17 axis in chronic hepatitis $\mathrm{C}$ virus infection and its treatment responses. Int J Mol Sci, 2016, 17(7):1070. https://doi.org/ 10.3390/ijms17071070 PMID: 27428948 PMCID: PMC 4964446

[108] Hao C, Zhou Y, He Y, Fan C, Sun L, Wei X, Wang L, Peng M, Wang $\mathrm{P}$, Lian J, Jia Z. Imbalance of regulatory $T$ cells and T helper type 17 cells in patients with chronic hepatitis C. Immunology, 2014, 143(4):531-538. https://doi.org/10.1111/ imm.12330 PMID: 24903732 PMCID: PMC4253501

[109] Rusu E, Jinga M, Rusu F, Ciurtin C, Enache G, Dragomir A, Cristescu V, Stoica V, Costache A, Cheta D, Radulian G. Statin therapy in patients with diabetes and hepatitis C. Farmacia, 2013, 61(6):1204-1215.

[110] Sahoo M, Ceballos-Olvera I, del Barrio L, Re F. Role of the inflammasome, IL-1 $\beta$, and IL-18 in bacterial infections. ScientificWorldJournal, 2011, 11:2037-2050. https://doi.org/ 10.1100/2011/212680 PMID: 22125454 PMCID: PMC 3217589
[111] Ulland TK, Sutterwala FS. Activation of the inflammasome by bacterial pathogens. In: Couillin I, Pétrilli V, Martinon F (eds). The inflammasomes. Book Series "Progress in Inflammation Research", Springer, Basel, 2011, 37-50. https://doi.org/10. 1007/978-3-0348-0148-5_3

[112] Zdrîncă M, Muțiu G, Bogdan M, Dobjanschi L, Antonescu A, Moş I, Mureşan $M$, Zdrîncă $M$, Antonescu A. Effects of Alprazolam, Zolpidem, and Zopiclone, and of chronic inflammation on peripheral experimental algesia in Wistar rats. Rom J Morphol Embryol, 2011, 52(1 Suppl):471-474. PMID: 21424095

[113] Latz E, Xiao TS, Stutz A. Activation and regulation of the inflammasomes. Nat Rev Immunol, 2013, 13(6):397-411. https://doi.org/10.1038/nri3452 PMID: 23702978 PMCID: PMC3807999

[114] Barbulescu AL, Ciurea PL, Mitran C, Chisalau BA, Parvanescu CD, Firulescu SC, Balasoiu M, Boldeanu MV, Popoviciu $\mathrm{H}$, Vreju FA. High frequency ultrasonography of the hand versus anti-RA33 evaluation in early rheumatoid arthritis - a pilot study. Med Ultrason, 2017, 19(2):166-171. https://doi.org/10.11152/mu-995 PMID: 28440350

[115] Hornung V, Ablasser A, Charrel-Dennis M, Bauernfeind F, Horvath G, Caffrey DR, Latz E, Fitzgerald KA. AIM2 recognizes cytosolic dsDNA and forms a caspase-1-activating inflammasome with ASC. Nature, 2009, 458(7237):514-518. https:// doi.org/10.1038/nature07725 PMID: 19158675 PMCID: PMC2726264

[116] Allen IC, Scull MA, Moore CB, Holl EK, McElvania-TeKippe E, Taxman DJ, Guthrie EH, Pickles RJ, Ting JPY. The NLRP3 inflammasome mediates in vivo innate immunity to influenza A virus through recognition of viral RNA. Immunity, 2009, 30(4):556-565. https://doi.org/10.1016/j.immuni.2009.02.005 PMID: 19362020 PMCID: PMC2803103

[117] Pothlichet J, Meunier I, Davis BK, Ting JPY, Skamene E, von Messling V, Vidal SM. Type I IFN triggers RIG-I/TLR3/ NLRP3-dependent inflammasome activation in influenza A virus infected cells. PLoS Pathog, 2013, 9(4):e1003256. https://doi.org/10.1371/journal.ppat.1003256 PMID: 23592984 PMCID: PMC3623797

[118] Kuriakose T, Kanneganti TD. Regulation and functions of NLRP3 inflammasome during influenza virus infection. Mol Immunol, 2017, 86:56-64. https://doi.org/10.1016/j.molimm. 2017.01.023 PMID: 28169000 PMCID: PMC5453821

[119] Johnson KE, Chikoti L, Chandran B. Herpes simplex virus 1 infection induces activation and subsequent inhibition of the IFI16 and NLRP3 inflammasomes. J Virol, 2013, 87(9):50055018. https://doi.org/10.1128/JVI.00082-13 PMID: 23427152 PMCID: PMC3624293

[120] Nour AM, Reichelt M, Ku CC, Ho MY, Heineman TC, Arvin AM. Varicella-zoster virus infection triggers formation of an interleukin-1 $\beta$ (IL-1 $\beta$ )-processing inflammasome complex. J Biol Chem, 2011, 286(20):17921-17933. https://doi.org/ 10.1074/jbc.M110.210575 PMID: 21385879 PMCID: PMC 3093867

[121] Rathinam VAK, Jiang Z, Waggoner SN, Sharma S, Cole LE, Waggoner L, Vanaja SK, Monks BG, Ganesan S, Latz E, Hornung V, Vogel SN, Szomolanyi-Tsuda E, Fitzgerald KA. The AIM2 inflammasome is essential for host defense against cytosolic bacteria and DNA viruses. Nat Immunol, 2010, 11(5): 395-402. https://doi.org/10.1038/ni.1864 PMID: 20351692 PMCID: PMC2887480

[122] Reinholz M, Kawakami Y, Salzer S, Kreuter A, Dombrowski Y, Koglin S, Kresse S, Ruzicka T, Schauber J. HPV16 activates the AIM2 inflammasome in keratinocytes. Arch Dermatol Res, 2013, 305(8):723-732. https://doi.org/10.1007/s00403-0131375-0 PMID: 23764897

[123] Kumar B, Ramachandran A, Waris G. Chapter 2: Hepatitis C virus and inflammation. In: Shahid I (ed). Hepatitis C - from infection to cure. IntechOpen, 2018, https://www.intechopen. $\mathrm{com} /$ books/hepatitis-c-from-infection-to-cure/hepatitis-c-virusand-inflammation. https://doi.org/10.5772/intechopen.75916

[124] Coutermarsh-Ott S, Eden K, Allen IC. Beyond the inflammasome: regulatory NOD-like receptor modulation of the host immune response following virus exposure. J Gen Virol, 2016, 97(4):825-838. https://doi.org/10.1099/jgv.0.000401 PMID: 26763980 PMCID: PMC4854363 
[125] Abderrazak A, Syrovets T, Couchie D, El Hadri K, Friguet B, Simmet T, Rouis M3. NLRP3 inflammasome: from a danger signal sensor to a regulatory node of oxidative stress and inflammatory diseases. Redox Biol, 2015, 4:296-307. https:// doi.org/10.1016/j.redox.2015.01.008 PMID: 25625584 PMCID: PMC4315937

[126] Albu CV, Pădureanu V, Boldeanu MV, Bumbea AM, Enescu AŞ, Albulescu DM, Siloşi CA, Enescu A. Vascular neurocognitive disorders and the vascular risk factors. J Mind Med Sci, 2018, 5(1):7-15. https://doi.org/10.22543/7674.51.P715

[127] Kufer TA, Fritz JH, Philpott DJ. NACHT-LRR proteins (NLRs) in bacterial infection and immunity. Trends Microbiol, 2005 , 13(8):381-388. https://doi.org/10.1016/j.tim.2005.06.004 PMID: 15994078

[128] Martinon F, Tschopp J. Inflammatory caspases and inflammasomes: master switches of inflammation. Cell Death Differ, 2007, 14(1):10-22. https://doi.org/10.1038/sj.cdd.4402038 PMID: 16977329

[129] Bărbulescu AL, Sandu RE, Vreju AF, Ciurea PL, Criveanu C, Firulescu SC, Chisălău AB, Pârvănescu CD, Ciobanu DA Radu M, Pădureanu V, Boldeanu MV, Albu VC. Neuroinflammation in systemic lupus erythematosus - a review. Rom J Morphol Embryol, 2019, 60(3):781-786. PMID: 31912087

[130] Boaru SG, Borkham-Kamphorst E, Tihaa L, Haas U, Weiskirchen R. Expression analysis of inflammasomes in experimental models of inflammatory and fibrotic liver disease.
J Inflamm (Lond), 2012, 9(1):49. https://doi.org/10.1186/ 1476-9255-9-49 PMID: 23192004 PMCID: PMC3599703

[131] Sun Q, Gao W, Loughran P, Shapiro R, Fan J, Billiar TR, Scott MJ. Caspase 1 activation is protective against hepatocyte cell death by up-regulating beclin 1 protein and mitochondrial autophagy in the setting of redox stress. J Biol Chem, 2013, 288(22):15947-15958. https://doi.org/ 10.1074/jbc.M112.426791 PMID: 23589298 PMCID: PMC 3668750

[132] Taxman DJ, Holley-Guthrie EA, Huang MTH, Moore CB Bergstralh DT, Allen IC, Lei Y, Gris D, Ting JPY. The NLR adaptor ASC/PYCARD regulates DUSP10, mitogen-activated protein kinase (MAPK), and chemokine induction independent of the inflammasome. J Biol Chem, 2011, 286(22):1960519616. https://doi.org/10.1074/jbc.M111.221077 PMID: 21487011 PMCID: PMC3103340

[133] Chen W, Xu Y, Li H, Tao W, Xiang Y, Huang B, Niu J, Zhong J, Meng G. HCV genomic RNA activates the NLRP3 inflammasome in human myeloid cells. PLoS One, 2014, 9(1):e84953. https://doi.org/10.1371/journal.pone.0084953 PMID: 24400125 PMCID: PMC3882267

[134] Guarda G, Braun M, Staehli F, Tardivel A, Mattmann C, Förster I, Farlik M, Decker T, Du Pasquier RA, Romero P, Tschopp J. Type I interferon inhibits interleukin-1 production and inflammasome activation. Immunity, 2011, 34(2):213-223. https://doi.org/10.1016/j.immuni.2011.02.006 PMID: 21349431

\section{Corresponding authors}

Andreea Lili Bărbulescu, Lecturer, MD, PhD, Department of Pharmacology, University of Medicine and Pharmacy of Craiova, 2 Petru Rareş Street, 200349 Craiova, Dolj County, Romania; Phone +40743-122 002, e-mail: anbarbulescu@gmail.com

Cristian Adrian Siloşi, Lecturer, MD, PhD, Department of Surgery, University of Medicine and Pharmacy of Craiova, 2 Petru Rareş Street, 200349 Craiova, Dolj County, Romania; Phone +40726-323 242, e-mail: cristian_silosi@yahoo.fr 